\title{
NFATC4 wt Allele
}

National Cancer Institute

\section{Source}

National Cancer Institute. NFATC4 wt Allele. NCI Thesaurus. Code C93156.

Human NFAT C4 wild-type allele is located in the vicinity of $14 q 11.2$ and is approximately $14 \mathrm{~kb}$ in length. This allele, which encodes nuclear factor of activated T-cells, cytoplasmic

4 , plays a role in the mediation of inflammation, transcription of cytokine genes and cellular differentiation. 